\title{
Analyzing Online Shopping Behavior from the Perspective of Youtube: Do Vlog Content and Vlogger Characteristics Matter
}

DOI: $10.26466 /$ opus. 874722

\author{
* \\ Aslı Tolunay* - Hüseyin Ekizler ** \\ *Doç. Dr., Yeditepe Üniversitesi, İ̈BF, İstanbul/Türkiye \\ E-Mail: asli.tolunay@yeditepe.edu.tr \\ ORCID: 0000-0003-3856-8518 \\ **Dr. Öğr. Üyesi, Marmara Üniversitesi, İşletme Fakültesi, İstanbul/Türkiye \\ E-Mail hekizler@marmara.edu.tr \\ ORCID: 0000-0001-5903-713X
}

\begin{abstract}
Video blogs (Vlogs) and video bloggers (Vloggers) have gained importance in marketing with their entertaining and educational content as they are attracting huge numbers of viewers and are therefore shaping many consumers' attitudes and purchase decisions. Research on vlogs concentrated on content characteristics, vlogger characteristics and general vlog features. However, this stream of research is fragmented, mostly ignores vlog audience motivations and lacks empirical investigations that parsimoniously study influence of certain vlog and vlogger characteristics on consumers' online purchase decisions. The purpose of this study is to explore the impact of vlog content value in terms of informativeness and entertainment and vlogger personal characteristics such as authoritative and engagement knowledge on consumers' information satisfaction and further on their intention to shop online. With this aim, data were gathered via an online survey from 627 purposively sampled respondents and a theoretical structural equation model was tested. Vlog content's informative and entertaining value and authoritative knowledge of the vlogger were found to be important factors explaining information satisfaction, whereas the effect of engagement knowledge on information satisfaction was insignificant. Furthermore, strong impact of information satisfaction on intention to shop online was determined. Managerial and theoretical implications are discussed in the paper.
\end{abstract}

Keywords: Vlog content value, vlogger personal characteristics, online shopping intention, information satisfaction 


\section{Online Alışveriş Davranışının Youtube Perspektifinden Analizi: Vlog İçeriği ve Vlogger Özellikleri Etkili Mi?}

Öz

Video blogları (Vlog'lar) ve video blog içerik üreticileri (Vlogger'lar), eğlenceli ve eğitici içerikleriyle çok sayıda izleyiciyi cezbettikleri için tüketicinin tutumlarını ve satın alma kararların şekillendirmelerinden dolayı pazarlamada önem kazanmıştır. Vloglar üzerine yapılan çalışmalar içerik özellikleri, vlogger özellikleri ve genel vlog özellikleri üzerinde yoğunlaşmıştır. Ancak bu çalışmaların birbirinden kopuk olduğu ve vlog izleyen kitlenin motivasyonlarını göz ardı ettiği ve belirli vlog içeik ve vlogger özelliklerinin tüketicilerin çevrimiçi satın alma kararlarına etkisini ayrıntılı bir şekilde inceleyen empirik çalışmalardan yoksun olduğu görülmektedir. Bu çalışmanın amacı, bilgi ve eğlence açısından vlog içerik değerinin ve yetkili bilgisi ve katılım bilgisi gibi vlogger kişisel özelliklerinin tüketicilerin bilgi memnuniyeti ve ayrıca çevrimiçi alışveriş yapma niyetleri üzerindeki etkisini araştırmaktır. Bu amaçla, veriler kasıtlı olarak örneklenmiş 627 katılımoıdan çevrimiçi anket yoluyla toplanmış ve teorik bir yapısal eşitlik modeli test edilmiştir. Vlog içeriğinin bilgilendirici ve eğlenceli değeri ve vloggerın yetkili bilgisi, bilgi memnuniyetini açıklayan önemli faktörler olarak bulunurken, etkileşim bilgisinin bilgi memnuniyeti üzerindeki etkisi anlaml bulunmamıştır. Ayrıca bilgi memnuniyetinin online alışveriş yapma niyeti üzerindeki güçlü etkisi tespit edilmiştir. Yönetsel ve teorik çıkarımlar makalede tartışılmaktadır.

Anahtar Kelimeler: vlog içerik değeri, vlogger kişisel özellikleri, online alışveriş niyeti, bilgi memnuniyeti 


\section{Introduction}

In today's competitive environment, with 3.8 billion users worldwide (Global Digital Yearbook, 2020), social media have become the most powerful and unavoidable communication tool for marketers. While consumers can express themselves and share their ideas and experiences about life, people, products and brands with each other and with companies easily (Veloutsou and Delgado-Ballester, 2019), with Social Media platforms, marketers can also reach consumers more directly and effectively (Kozinets, De Valck, Wojnicki, and Wilner, 2010). Therefore, social media are believed to develop and enhance brand equity (Godey et al., 2016), engagement (Dessart, 2017), knowledge (Cheung et al., 2020) and more importantly shape consumers' consumption related decisions (Webster, 2010). Whilst the hyperconnected Social Media platforms enable constant information flow, connectivity and more stronger relationships (Swaminathan et al., 2020) both for brands and consumers and the effects of many Social media platforms such as Instagram, YouTube, Twitter and Facebook on consumer decision making and purchase is undeniable (Webster, 2010), the characteristics of each platform is unique (Smith, Fischer, and Yongjian, 2012) giving rise to different type of contents and benefits (Lee and Watkins, 2016).

Among the popular Social Media platforms, blogs and recently video blogs (vlogs), play a significant role for companies for their content marketing strategies. Vlogs, either created by the companies or by professional or amateur users (vloggers), are videos shared on YouTube and enable companies reach new markets and increase brand preference and knowledge (Batra and Keller, 2016). More importantly, as vloggers produce and share videos about their personal life and personal product or brand experiences (Lee and Watkins, 2016), vlogs generate identification (Brouwer, 2015), interaction (Brouwer, 2015) and intimacy (Lee, 2020) among the followers and are perceived as user generated content by some consumers (Stein, Koban, Joos, and Ohler, 2020) being regarded by many as trustful sources for their purchase decisions (Barker, Barker, Bormann, and Neher, 2017). Although many of the vlogs are sponsored content (Jans, Cauberghe, and Hudders, 2018), the popularity of vlogs as sources of information has turned them into a 
competitive medium against traditional media (Gürkaynak and Kama, 2018) and created a million-dollar business for vloggers through sponsors (Lynch, 2018).

Recent research on vlogs' influence on consumption decisions concentrates on (1) content characteristics such as being amateur and professional (Stein et al., 2020) or authentic (Cunningham and Craig, 2017), (2) vlogger characteristics such as popularity, expertise (Ladhari, Massa, and Skandrani, 2020), credibility (Munnukka, Maityb, Reinikainena, and Luoma-aho, 2019; Sakib, Zolfagharianb and Yazdanparast, 2020) or physical and social attractiveness (Liu, Liu, and Zhang, 2019; Sakib et al., 2020), (3) audiences motivations such as gaining information, being entertained, building a social network of likeminded individuals (Liu et al., 2019) and self-presentation (Harnish and Bridges, 2016) and (4) general vlog features such as level of audience participation and interaction (De Jans et al., 2018; Munnukka, et al., 2019) and sensory and social elements (Zhang, 2018). However, this stream of research is fragmented, mostly ignores the values offered by vlogs derived from vlog followers' motivations and lacks empirical investigations that parsimoniously study influence of certain vlog and vlogger characteristics on consumers' purchase decisions.

Against this background, the current study focuses on vlog content characteristics such as informativeness and entertainment from the perspective of the values followers look for within vlogs and on vlogger characteristics such as engagement knowledge and authoritative knowledge and tries to identify their influence on viewers' information satisfaction and purchase intention. With this aim, the study initially reviews the literature, presents the methodology of the study, which are followed with the findings of the statistical analyses. The study concludes with a discussion of the findings as well as managerial and theoretical contributions and future research directions.

\section{YouTube, Vlogs and Vloggers}

Today, along with Facebook and Instagram, YouTube is among the third most visited Social Media platforms in the whole world (Nyagadza, 2020). Users of YouTube may create personal profiles to post their own 
videos and view and comment to videos that are posted by other users. While anybody can produce and upload any kind of video on the platform, highly watched and influential ones are mostly produced by professionals (Kruitbosch and Nack, 2008) and are in the form of vlogs, music videos, live performances, consumption and experience videos, product reviews such as unboxing videos or comedy performances (Blythe and Cairns, 2009; Burgess and Green, 2009), reaching a large number of users from different parts of the world. Hence, with many different forms that can attract different types of audiences, YouTube has become an important Social Media medium for brands and consumers (Singh and Sonnenburg, 2012; Smith, Fischer, and Yongjian, 2012).

Among the content types available in YouTube, vlogs, which are "informal communications directed at other consumers about the ownership, usage, or characteristics of particular goods and services" (Westbrook, 1987, p.261) are similar to their written counterparts, blogs, and contain visual documentations about the lives and ideas of video bloggers, vloggers (Hill et al., 2017). Vlogs include several types such as haul videos of purchased products, $Q$ and as and fan videos, reviews of products or do-it-yourself videos with recipes or tips of all kinds (Zhang, 2018). They are viewed by large audiences and with their authentic (Cunningham and Craig, 2017), credible (Johnson and Kaye, 2004) and realistic nature, they attract millions of watchers (Lee and Watkins, 2016) and therefore are more influential on individuals' purchase decisions than any other type of content available on social media (Burgess and Green; 2009; Djafarova and Rushworth, 2017). As a result, some YouTube vlog content creators, vloggers, with their enormous audience sizes have become "social celebrities" (Hsu, Huang, Ko, and Wang, 2013) and real influencers (Stein et al., 2020), such that vlogs have gained managerial importance (Lee and Watkins, 2016).

Whilst the influence of social media on consumer decision making and shopping intentions is an inevitable reality for consumers and companies (Swaminathan, 2016), in terms of the effect of vlogs on consumers' consumption decisions and behaviors, previous research provided vast amount of evidence. Studies report that vloggers' trustworthiness (Rahmi, Sekarasih and Sjabadhyn, 2016), expertise (Wang, 2015; Weismüller, Harrigan, Wang, and Soutar, 2020) and 
popularity (Ladharia et al., 2020) and the persuasiveness of the messages (Ramadanty, Muqarrabin, Nita, and Syafganti, 2020) are among the factors that affect purchase and impulse buying intentions of the viewers (Arviansyah, Dhaneswara, Hidayanto, and Zhu, 2018). While vlogs are valuable for companies and brands to connect with the consumers, raise awareness and create brand-related attitude and knowledge (Munnukka et al., 2019), latest research mainly concentrates on the audiences' motives (Harnish and Bridges, 2016; Munnukka et al., 2019) and preferences in vlog content and vloggers (Cunningham and Craig, 2017; Munnukka et al., 2019; Stein et al., 2020) to attract more audiences and to influence purchase intentions.

\section{Vlog Content Value}

According to previous research, individuals are viewing vlogs on YouTube to fulfill self-enhancement motivations (Khan, 2017), to feel socialized with individuals with similar values (Harnish and Bridges, 2016; Liu et al., 2019), but mostly to get information from and to be entertained by the content shared by vloggers (Khan, 2017; Liu et al., 2019).

Informativeness of a vlog is defined as "the degree of how much information about a product in the vlog can be helpful for the viewers" (Arviansyah et al., 2018, p.251) According to Ducoffe (1996) level of informativeness of an advertisement depends on the capability of the advertisement to make consumers satisfied in providing some helpful information concerning any product or any service. Similarly, previous research on vlogs documents that viewer watch the content mainly for the information provided (Choi and Behm-Morawitz, 2017; Dehghani, Niaki, Ramezani, and Sali, 2016) motivating their consumption and participation (Haridakis and Hanson, 2009; Ladhari, Massa and Skandrani, 2020).

Whilst consumers need a great deal of information in simplifying their consumption decisions, they also look to satisfy their needs for daydreaming, distortion, aesthetic pleasure or affective freedom (McQuail, 1983). In the advertising value context, previous researchers have demonstrated that the entertainment content has a positive impact 
on advertising value (Ducoffe 1995; Haghirian, Madlberger and Tanuskova, 2005; Ko, Cho, and Roberts, 2005). In a similar fashion, vlogs have been referred as "Social Media entertainment" (Cunningham and Craig, 2017) that are serving to the viewers' hedonic needs (Parboteeah, 2005) and have been documented to be viewed (Khan, 2017) and to be instrumental in brand choices (Liu et al., 2019) by the level of entertainment they provided.

While vlogs created for certain products (such as beauty vs. computers) might show differences in their levels of informativeness and entertainment, the reasons why individuals consume vlogs in general are still particularly important. Depending on the overall assessment of audience expectations and what the vlogs are offering (Zeithaml, 1988), vlogs need to display certain characteristics to create value for the YouTube audience, regardless of being regarded as advertising (De Jans et al., 2018) or user-generated content (Lee and Watkins, 2016) by the consumers. According to the advertising value model (Ducoffe, 1996), which was applied to describe consumers' value perceptions towards advertisements on digital environments (Murillo et al., 2016), individuals evaluate the value of an advertisement based on mainly two factors, which are entertainment and informativeness (Ducoffe, 1995). Based on this and the discussion above, we suggest that just like advertisements, the value of video content is also a subjective assessment of the relative value efficacy of that video by the followers based on the informativeness and entertainment character of the content. Hence, content that is entertaining and informative that matches with the expectations of the YouTube audience would provide value for them and might be important in strengthening the satisfaction of vlog followers. Accordingly, we develop the following hypotheses:

H1a: Informativeness has a positively effect on information satisfaction.

$\mathrm{H} 1 \mathrm{~b}$ : Entertainment has a positive effect on information satisfaction.

\section{Vloggers Personal Characteristics}

Studies on vlogs mention that viewers prefer professional vlogs (Stein et al., 2020) and identify vloggers' characteristics that signify 
professionalism such as expertise and credibility (Chapple and Cownie, 2017; Hill et al., 2017; Sakib et al., 2020) as well as physical and social attractiveness (Chapple and Cownie, 2017; Liu et al., 2019) to influence viewers' brand related knowlegde (Liu et al., 2019) and buying intentions (Hill et al., 2017; Munnukka et al., 2019). In the context of blogs, Doyle et al. (2012) identifies authoritative and engagement knowledge as two human-capital ability sources that not only determine trust in the blog but also create desirable outcomes in the readers. The definition of authoritative knowledge is very straightforward. Individuals have authoritative knowledge "on the basis of exercising authority" (Glasscock, 2020, p.8) and it is non-dependent whether they have direct experience or not. Given that vloggers are either reporting their own or others' experiences and are believed to own knowledge on the topic area, they are supposed to have authoritative knowledge. In contrast, engagement knowledge is gathered in a longitudinal fashion through the topic area "participation", deliberate communal activity including both time and engagement (Bagotzzi and Dholakia, 2002). Therefore, engagement knowledge is directly related to the vlogger's participation to the topic area (Doyle et al., 2012) and is developed through involvement with the real, lived experiences of the vlogger. Hence, vloggers' personal characteristics and their own interests that pave the way to authoritative and engagement knowledge play a role in persuading consumers and satisfying their needs in terms of the content shared (Doyle et al., 2012).

Given that vlogs are similar in nature to blogs in many aspects (Griffith and Papacharissi, 2010), we believe that those two characteristics of the vlogger will be effective in viewers' satisfaction. Hence, based on the discussion above, the following hypotheses were formulated.

H2a: Authoritative knowledge has a positive effect on information satisfaction.

$\mathrm{H} 2 \mathrm{~b}$ : Engagement knowledge has a positive effect on information satisfaction. 


\section{Information Satisfaction}

Information satisfaction can be described as "the extent to which users believe the information system available to them meets their information requirements" (Ives, Olson and Baroudi, 1983). While individuals watch vlogs both for their entertaining and informative nature, vlogs became solid information sources for most of the viewers (Lee and Watkins, 2016) as previous studies illustrated that information which has high levels of quality and meaning are beneficial for both the overall community and individual followers (Koh, Kim, and Kim 2003). Consequently, when a vlog is able to provide information, which the followers are valuing, ahead of any other competition, satisfaction with the information obtained from the vlog increases and not only time spent on the vlog rises but also the number of the viewers (Hsu et al., 2013; Wang and Chang, 2020). As a result, vloggers posting or sharing a video consisting of product reviews assist many consumers while shopping online or shape their purchase decisions (Liu, Liu, and Zhang, 2019; Stein et al., 2020). Accordingly, the following hypothesis has been formulated.

H3: Information satisfaction has a positive effect on intention to shop online.

Based on the discussion above, the conceptual model of the study is represented below in Figure 1.

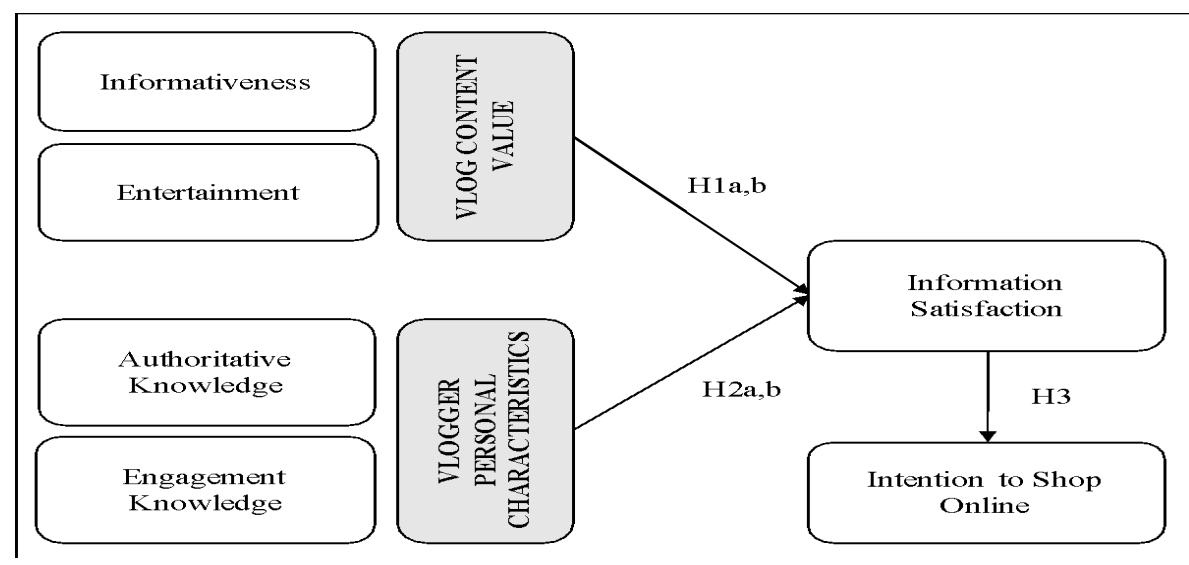

Figure 1. Conceptual Framework 


\section{Methodology}

\section{Instruments}

Data to measure the constructs in the study have been collected using previously validated scales with high construct validity, while minor variations in the wording of the questions were done to adjust the items to the study setting.

Table 1 Measurement items

\begin{tabular}{|c|c|c|}
\hline Construct & Item & Source \\
\hline Entertainment & $\begin{array}{l}\text { ENT1 This vlog is entertaining. } \\
\text { ENT2 This vlog is enjoyable. } \\
\text { ENT3 This vlog is pleasing. } \\
\text { ENT4 This vlog is fun to use. } \\
\text { ENT5 This vlog is exciting. }\end{array}$ & \multirow[b]{2}{*}{ Ducoffee, 1996} \\
\hline Informativeness & $\begin{array}{l}\text { INF3 This vlog provides timely information. } \\
\text { INF4 This vlog is a good source of up-to-date product } \\
\text { information. } \\
\text { INF5 This vlog makes product information immediately } \\
\text { accessible. } \\
\text { INF6 This vlog is a convenient source of product information. } \\
\text { INF7 This vlog supplies complete product information. }\end{array}$ & \\
\hline $\begin{array}{l}\text { Engagement } \\
\text { Knowledge }\end{array}$ & $\begin{array}{l}\text { EW1 Has wide-ranging experience. } \\
\text { EW2 Has extensive experience in the area. } \\
\text { EW3 Has resources that others do not. } \\
\text { EW4 Is heavily involved in the area. } \\
\text { EW5 Is passionate about the topic. } \\
\text { EW6 Is very critical in discussing the topic. } \\
\text { EW7 Is very engaged in the topic field. } \\
\text { EW8 Is interested in topic-area improvements. } \\
\text { EW9 Spends a lot of time studying the topic. } \\
\text { EW10 Knows about unusual aspects of the topic. } \\
\text { EW11 Uses correct terminology. }\end{array}$ & \multirow[t]{2}{*}{ Doyle et al., 2012} \\
\hline $\begin{array}{l}\text { Authoritative } \\
\text { Knowledge }\end{array}$ & $\begin{array}{l}\text { AW5 Has written a book about the topic. } \\
\text { AW6 Has specialized education in the topic area. } \\
\text { AW8 Writes about the topic in mainstream media. }\end{array}$ & \\
\hline $\begin{array}{l}\text { Information } \\
\text { Satisfaction }\end{array}$ & $\begin{array}{l}\text { IS1 I can find the information I want on this Vlog. } \\
\text { IS2 I can easily find information I want on this Vlog. } \\
\text { IS3 I can find a wealth of information I want on this Vlog. }\end{array}$ & Hsu et al., 2014 \\
\hline $\begin{array}{l}\text { Online Shoppin } \\
\text { Intention }\end{array}$ & $\begin{array}{l}\text { ITS1 I will frequently shop online in the near future. } \\
\text { gITS2 I will strongly recommend others to shop online. } \\
\text { ITS3 Vlogs are a good way to shop online. } \\
\text { ITS4 I will continue using Vlogs to shop online in the future. }\end{array}$ & $\begin{array}{l}\text { To et al., 2007; Hsu } \\
\text { et al., } 2013\end{array}$ \\
\hline
\end{tabular}


All questions were translated into Turkish and then back translated by a group of academicians fluent in English and Turkish to assure face validity and were gauged on five-point Likert scales ranging from 1 (strongly disagree) to 5 (strongly agree). Vlog content value measures were derived from Ducoffee (1996), with two sub-dimensions Entertainment and Informativeness. Vlogger personal characteristics' measures were derived from Doyle et al. (2012) with Engagement Knowledge and Authoritative Knowledge as the sub-dimensions. To measure Information Satisfaction three items by Hsu et al. (2014) were used and finally to measure Online Shopping Intention four items were adapted from To, Liao, and Lin (2007) and Hsu et al. (2013). Scales, their sources and corresponding items are listed in Table 1.

\section{Sample and Data Collection}

As the topic of the study involves online interaction, an online survey in Turkish was developed and distributed through a link on Social Media platforms. In order to ensure validity of the findings, two context-related screening questions were used (1- "Do you follow any Vloggers?" and 2"Who is your favorite Vlogger?") to eliminate invalid responses. Convenience sampled participants who were able to pass those questions were directed to the questionnaire and were asked to provide their answers with regards to the Vlogger they named in the second question. Finally, they provided demographic and descriptive information about themselves and their Social Media usage. This procedure yielded a total of 758 responses. After cleaning the participants with missing, inconsistent and illogical responses, 627 completed surveys were available for further analysis.

The respondents were 18 to 60 years old with a mean of 28.30 and standard deviation of 7.34. The majority of respondents were female $(65.6 \%)$ and had undergraduate and graduate degrees (90\%). The sample consisted of at least one-year Vlog subscribers and majority of the respondents (59.9\%) were following Vlogs at least for two years. $72.8 \%$ of respondents indicated they are spending 1 to 3 hours per day on internet sites and $69.2 \%$ of respondents are on social media platforms for 1 to 3 
hours per day. Descriptive statistics of the sample are provided in Table 2.

Table 2 Descriptive statistics of the sample's characteristics

\begin{tabular}{llll}
\hline \multirow{2}{*}{ Gender } & & Number & Percentage \\
\hline \multirow{2}{*}{ Marital Status } & Female & 411 & $65.6 \%$ \\
& Male & 216 & $34.4 \%$ \\
\hline \multirow{5}{*}{ Education } & Married & 180 & $28.7 \%$ \\
& Single & 447 & $71.3 \%$ \\
\hline \multirow{5}{*}{ Income } & High School & 63 & $10.0 \%$ \\
& University & 409 & $65.2 \%$ \\
& Graduate & 144 & $23.0 \%$ \\
& PhD & 11 & $1.8 \%$ \\
\hline & $0-1000 \mathrm{TL}$ & 89 & $14.2 \%$ \\
& $1001-2000 \mathrm{TL}$ & 117 & $18.7 \%$ \\
& $2001-3000 \mathrm{TL}$ & 127 & $20.3 \%$ \\
& $3001-4000 \mathrm{TL}$ & 116 & $18.5 \%$ \\
& More than $4001 \mathrm{TL}$ & 178 & $28.4 \%$ \\
\hline
\end{tabular}

\section{Findings}

\section{Construct Validity Analyses}

Construct validity refers to the fit between the data obtained by the measures used in the study and the theoretical model (Sekaran and Bougie, 2016) and is assessed by the reliability and nomological, discriminant and convergent validity (Peter, 1981). To test the construct validity, as suggested by Lattin, Carroll and Green (2003), two different samples taken from the overall sample was used to run an exploratory factor analysis (EFA) followed by a confirmatory factor analysis (CFA). As a result, half of the sample $(n=319)$ was selected randomly by SPSS with Bernoulli distribution to explore the underlying item structure in EFA, while a holdout sample $(n=308)$ was used for CFA to confirm that structure.

EFA was performed with Principal Component Factoring with Varimax Rotation which is an orthogonal rotation method assuming factors uncorrelated throughout the rotation giving a clearer separation of the factors (Hair, Black, Babin, Anderson, and Tatham, 1998). Four items from the factor "Engagement Knowledge" (EW1, EW2, EW3, EW6) 
were eliminated from the analysis due to either double loading or loadings being less than 0.5 (Hair et al., 1998). The results of the final factor analysis confirmed the predicted item structure with significant correlations among variables indicating a sufficient level of shared variance $\left(\mathrm{KMO}=0.948\right.$, Bartlett test $\left.\chi^{2}(351)=9371.473, \mathrm{p}<0.01\right)$. Next, to test the internal consistency of factors, Cronbach's coefficient alpha reliabilities were computed. Reliabilities for all dimensions were above 0.70 threshold suggested by DeVellis (2003). The results of EFA, items under each factor and factor's reliabilities are given in Table 3.

Table 3. EFA and CFA Results

\begin{tabular}{|c|c|c|c|c|c|c|}
\hline \multirow[b]{2}{*}{ Factor/Items } & \multicolumn{3}{|l|}{ EFA } & \multicolumn{3}{|l|}{ CFA } \\
\hline & $\begin{array}{l}\text { Factor } \\
\text { Loading }\end{array}$ & $\begin{array}{l}\text { Varianc } \\
\text { e } \%\end{array}$ & Alpha & $\begin{array}{l}\text { Factor } \\
\text { Loading }\end{array}$ & CR & AVE \\
\hline \multicolumn{7}{|c|}{ Factor 1: Engagement Knowledge } \\
\hline EW5 & 0.793 & \multirow{7}{*}{20.195} & \multirow{7}{*}{0.949} & 0.915 & \multirow{7}{*}{0.961} & \multirow{7}{*}{0.779} \\
\hline EW4 & 0.784 & & & 0.883 & & \\
\hline EW7 & 0.752 & & & 0.894 & & \\
\hline EW8 & 0.751 & & & 0.923 & & \\
\hline EW9 & 0.710 & & & 0.878 & & \\
\hline EW10 & 0.709 & & & 0.850 & & \\
\hline EW11 & 0.699 & & & 0.832 & & \\
\hline \multicolumn{7}{|c|}{ Factor 2: Informativeness } \\
\hline INF5 & 0.816 & \multirow{5}{*}{16.738} & \multirow{5}{*}{0.946} & 0.937 & \multirow{5}{*}{0.960} & \multirow{5}{*}{0.828} \\
\hline INF6 & 0.811 & & & 0.946 & & \\
\hline INF4 & 0.763 & & & 0.935 & & \\
\hline INF3 & 0.755 & & & 0.914 & & \\
\hline INF7 & 0.736 & & & 0.811 & & \\
\hline \multicolumn{7}{|c|}{ Factor 3: Entertainment } \\
\hline ENT1 & 0.795 & \multirow{5}{*}{15.384} & \multirow{5}{*}{0.965} & 0.968 & \multirow{5}{*}{0.982} & \multirow{5}{*}{0.93} \\
\hline ENT4 & 0.792 & & & 0.956 & & \\
\hline ENT2 & 0.785 & & & 0.982 & & \\
\hline ENT3 & 0.769 & & & 0.957 & & \\
\hline ENT5 & 0.660 & & & 0.854 & & \\
\hline \multicolumn{7}{|c|}{ Factor 4: Intention to Shop Online } \\
\hline ITS1 & 0.816 & \multirow{4}{*}{10.706} & \multirow{4}{*}{0.849} & 0.767 & \multirow{4}{*}{0.869} & \multirow{4}{*}{0.624} \\
\hline ITS3 & 0.790 & & & 0.777 & & \\
\hline ITS2 & 0.685 & & & 0.793 & & \\
\hline ITS4 & 0.612 & & & 0.821 & & \\
\hline \multicolumn{7}{|c|}{ Factor 5: Authoritative Knowledge } \\
\hline AW6 & 0.918 & \multirow{3}{*}{10.346} & \multirow{3}{*}{0.905} & 0.796 & \multirow{3}{*}{0.812} & \multirow{3}{*}{0.591} \\
\hline AW5 & 0.900 & & & 0.757 & & \\
\hline AW8 & 0.812 & & & 0.752 & & \\
\hline Factor 6: Info & isfaction & & & & & \\
\hline IS2 & 0.695 & & & 0.962 & & \\
\hline IS1 & 0.670 & 8.727 & 0.936 & 0.938 & 0.952 & 0.869 \\
\hline IS3 & 0.629 & & & 0.895 & & \\
\hline
\end{tabular}


To validate the factors proposed by EFA and investigate the dimension structure in depth, confirmatory factor analysis (CFA) was conducted using AMOS Version 23. Goodness of fit indexes indicated a good model fit $\left(\chi^{2}(284)=567.427(\mathrm{p}<0.01) ; \quad \mathrm{CFI}=0.972 ; \mathrm{TFI}=0.966\right.$ RMSEA $=0.057$ ) (Hair et al., 1998) with the modification indices not indicating any further improvement in the model. Therefore, no other item was eliminated from the CFA model. Findings further confirmed construct validity in terms of composite reliability (CR), convergent and discriminant validities with the factor loadings of each variable exceeding 0.70 (Table 3), average variance extracted values (AVE) ranging between 0.591 to 0.933 , CR values ranging between 0.812 to 0.982 (Anderson and Gerbing 1988; Fornell and Larcker 1981), the correlations between each factor being less than 0.90 in absolute terms (Table 4) (Klein, 1998) and AVE values being higher than inter-construct correlations (Anderson and Gerbing, 1988; Fornell and Larcker, 1981).

Table 4 Means, Standard Deviations and Correlations

\begin{tabular}{lllllll}
\hline Variable & 1 & 2 & 3 & 4 & 5 & 6 \\
\hline 1. Intention to Shop Online & - & & & & & \\
2. Entertainment & $0.630^{*}$ & - & & & & \\
3. Informativeness & $0.600^{*}$ & $0.693^{*}$ & - & & & \\
4. Engagement Knowledge & $0.571^{*}$ & $0.766^{*}$ & $0.673^{*}$ & - & & \\
5. Authoritative Knowledge & $0.356^{*}$ & $0.360^{*}$ & $0.457^{*}$ & $0.557^{*}$ & - & \\
6. Information Satisfaction & $0.628^{*}$ & $0.740^{*}$ & $0.762^{*}$ & $0.686^{*}$ & $0.487^{*}$ & - \\
Mean & 3.321 & 3.488 & 3.176 & 3.377 & 2.593 & 3.240 \\
Standard Deviation & 0.980 & 1.112 & 1.065 & 1.069 & 1.046 & 1.103 \\
\hline
\end{tabular}

\section{Structural Model}

Next, the hypothesized structural model was tested using AMOS 23.0 with the overall sample $(\mathrm{N}=627)$. The initial model generated an acceptable fit, but the influence of vlogger's engagement knowledge on the audience's information satisfaction was turned to be insignificant. Therefore, the analysis was repeated with the vlogger's engagement knowledge being eliminated from the model (Figure 2). The results of this path analysis showed a good fit $(\chi 2(153)=636.234, \mathrm{p}<0.01$; $\mathrm{GFI}=0.910$; $\mathrm{AGFI}=0.876$; $\mathrm{CFI}=0.965$; $\mathrm{TLI}=0.956$; RMSEA=0.071) and are presented in Table 5. According to the analysis results, it was found that 
"Authoritative Knowledge" as one of the dimensions of vlogger personal characteristics explained "Information Satisfaction" significantly ( $\beta$ authoritative knowledge $=0.181, \mathrm{p}<0.01$ ), while the influence of "Vlog Content Value"s sub-dimensions "Entertainment" and "Informativeness" were found to affect "Information Satisfaction" more strongly (ßentertainment $=0.429, \quad \mathrm{p}=0.000 ; \quad$ informativeness $=0.497$ $\mathrm{p}<0.01)$. Results also indicated that "Intention to Shop Online" is significantly influenced by "Information Satisfaction" $(\beta=0.719, \mathrm{p}<0.01)$. Overall, as a summary, hypotheses H1a, H1b, H2a, H3 were supported, while hypothesis $\mathrm{H} 2 \mathrm{~b}$ was rejected.

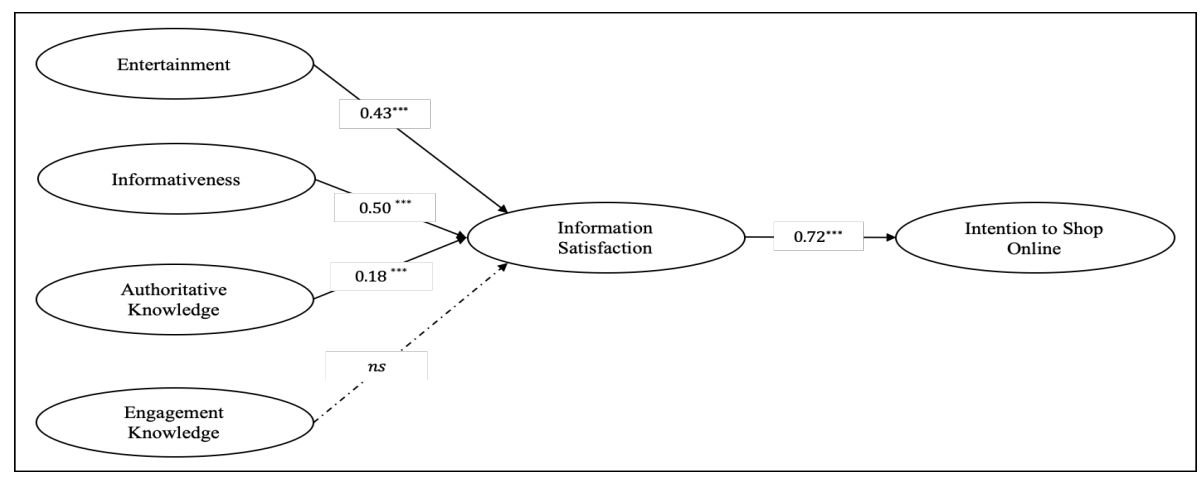

Figure 2 Graphical Representation of the Final Path Model

Table 5 Results of Path Models

\begin{tabular}{lll}
\hline & $\boldsymbol{\beta}$ & $\mathbf{t}$ \\
\hline Entertainment $\rightarrow$ Information Satisfaction & 0.429 & $12.179^{* * *}$ \\
Informativeness $\rightarrow$ Information Satisfaction & 0.497 & $11.955^{* * *}$ \\
Engagement $\rightarrow$ Information Satisfaction & $\mathrm{ns}$ & \\
Authoritative Knowledge $\rightarrow$ Information Satisfaction & 0.181 & $6.773^{* * *}$ \\
Information Satisfaction $\rightarrow$ Intention to Shop Online & 0.719 & $15.513^{* * *}$ \\
\hline$\chi^{2}(153, N=627)=636.234, p=0.000 ;$ GFI=0.910; CFI=0.965, AGFI=0.876, TLI=0.956, RMSEA=0.071 \\
Note. ${ }^{* * *} p<.001 G F I=$ Goodness of Fit; AGFI=Adjusted Goodness of Fit; CFI=Comparative Fit Index; TLI= \\
Tucker Lewis Fit Index; RMSEA=Root Mean Square Error Approximation; ns= not significant
\end{tabular}

\section{Discussion}

As consumers spend more time with social media, it is not surprising that YouTube, which is now one of the most common online platforms 
used to be entertained and informed, cultivates the potential to impact consumers' intentions to shop online. For this reason, this study examines the effects of vlogs content value and vloggers' personal characteristics on followers' information satisfaction and further on their intention to shop online.

Our findings illustrate that in terms of video content value, entertainment and informativeness have almost the same positive impact on consumers' information satisfaction. This finding is in line with YouTube becoming a more frequently used tool by the consumers not only to be entertained but also to get information about the latest offerings. In terms of vloggers' personal characteristics, the study provides evidence on authoritative knowledge being an important antecedent in information satisfaction of the vlog viewers. Unlike authoritative knowledge, engagement knowledge is found to exert no influence on information satisfaction. These findings indicate that vlog's informative and entertaining contents and authoritative knowledge as the vlogger personal characteristics are important to explain how to viewers' information satisfaction is generated. Authoritative knowledge refers to how much the vlogger is perceived by the followers as an authority in the field.

Among the important factors that impact the effect and reach of Social Media influencers, expertise increases credibility of the influencer (Hudders et al., 2020) leading them to be perceived more trustworthy by their followers (Biswas et al. 2006). In addition to the listed findings, the results show that vlog characteristics are by far important than vlogger characteristics contradicting previous studies (Hill et al., 2017; Munnukka et al., 2019; Stein et al., 2020), giving rise to the acknowledgment of the importance of the content over the source. Furthermore, in this study, it appears that there is a strong relationship between information satisfaction and intention to shop online. This result is consistent with previous studies indicating a strong link between vlogs and purchase intention (Hsu et al., 2013; Park, Lee and Han 2007; Wang, 2015). As a summary, results indicate that high levels of information satisfaction coming from vlog content value and vlogger's authoritative knowledge intensify consumers' intention to shop online. 


\section{Theoretical implications}

Theoretically this study advances knowledge in four ways. First, while previous studies investigate vlog content such as being amateur and professional (Stein et al., 2020) or authentic (Cunningham and Craig, 2017), and vlogger characteristics such as popularity, expertise (Ladhari et al., 2020), credibility (Munnukka et al., 2019; Sakib et al., 2020) or physical and social attractiveness (Liu et al., 2019; Sakib et al., 2020) and postulate links between those and consumers' shopping intentions, they are mostly fragmented and do not compare their influence with each other but rather discuss them individually. The results of this research, however, provide evidence that content characteristics are more important than vlogger characteristics in generating satisfaction. Second, while previous research identifies gaining information and being entertained (Liu et al., 2019) as audience motivations, studies do not take the assessment of vlog content based on these factors into consideration. Following the informative/entertaining content dichotomy in advertising and previous research on blog content into consideration, this research parsimoniously evaluates the value viewers gain from the content with respect to its informative and entertaining nature. Third, expertise, credibility (Chapple and Cownie, 2017; Hill et al., 2017; Sakib et al., 2019), trustworthiness (Choi and Lee, 2019) and physical and social attractiveness (Chapple and Cownie, 2017; Liu et al., 2019) of the vloggers have been identified as important factors shaping consumers attitudes and behavior. Yet, this particular study examines the impact of authoritative knowledge on information satisfaction as similar to expertise, credibility and trustworthiness authoritative knowledge has also been suggested in literature to induce trust among blog readers (Doyle et al., 2012). Hence, this study integrates a concept, that has not been taken into consideration before in this context, in the vlogging environment. Forth, although there is vast amount of research in marketing and consumer behavior illustrating that there is a relationship between consumer satisfaction and purchase intention (Anderson and Fornell 1994), the impact of information satisfaction on intention to shop online has not been examined yet. This study is one of its kind to analyze 
this relationship and contribute to the understanding of online purchase intention.

\section{Practical implications}

As managerial contribution, the findings of the study provide significant information for vloggers and brands that use vlogs to communicate with their consumers. In traditional advertising messages, brands are already aware that consumers are valuing both informative and entertaining content and more so a combination of both (Mark, 1993). With the results of this particular study, apparently both aspects of the vlog content satisfy consumers' expectations, which means that vloggers to create effective content need to look for a balance between fun and information in a similar way as it is in advertising. This finding is inline with the latest development of Social Media influence. Consumers are now not only consuming Social Media content just to be entertained but they would like to get information and be educated, as well. Very good examples are beauty vloggers. Among the most popular vlogger types, they share their own experiences with the products and educate viewers on which products to choose or how to use them. As such, Social Media influencers of any kind but more specifically vloggers need to adjust their content accordingly to keep a balance between fun and information.

The results also shed light to the brands' choice of the vloggers. If the aim of the brand is to assist consumers in their online consumption, brands need to choose vloggers who are perceived as authorities in the topic, rather than just individuals who are using the products and talking about their own experiences. Whilst Social Media content creators are perceived as credible sources of information, with many Social Media channels and many vloggers creating content to be consumed, consumers have become very selective in their choices. The results of this study highlight the fact, that getting the right information from an expert of the field is gaining importance. As a result, vloggers need to thrive a trustworthy and experienced image among their content consumers. 


\section{Limitations and Future research}

Despite the efforts of the researchers, this study has several limitations. The study, though purposively selected, uses a convenience sample that is leaning toward women and university education. Hence, the generalizability of the study is questionable. For future studies, we suggest employing a more diverse if not a probability sample. Moreover, as in every study in social sciences, the study is prone to several common method biases (Podsakoff, McKenzie, Lee, and Podsakoff, 2003), some of which such as measurement context effects can be prevented. Also, we recommend future studies to add other variables such as social competency to the vlogger personal characteristics. As a final limitation, this research only focuses on YouTube. Other scholars can also investigate other social media platforms that also display videos (i.e. Instagram, SnapChat) and compare results.

\section{References}

Anderson, E. W., and Fornell, C. (1994). A customer satisfaction research prospectus. Service quality: New directions in theory and practice, 14(1), 239-266.

Anderson, J. C. and Gerbing, D. W. (1988). Structural equation modeling in practice: A review and recommended two-step approach, Psychological Bulletin, 103(May), 411-423.

Arviansyah, Dhaneswara, A. P., Hidayanto, A. N., and Zhu, Y. Q. (2018). Vlogging: Trigger to impulse buying behaviors. In PACIS, 249-262.

Bagozzi, R. and Dholakia, U. (2002). Intentional social action in virtual communities, Journal of Interactive Marketing, 16(2), 2-21.

Barker, M., Barker, D. I., Bormann, N. F., and Neher, K. E. (2012). Social media marketing: A strategic approach. Nelson Education.

Batra, R., and Keller, K. L. (2016). Integrating marketing communications: New findings, new lessons, and new ideas. Journal of Marketing, 80(6), 122-145.

Biswas, D., Biswas, A., and Das, N. (2006). The differential effects of celebrity and expert endorsements on consumer risk perceptions. The role of consumer knowledge, perceived congruency, and product technology orientation. Journal of advertising, 35(2), 17-31. 
Blythe, M., and Cairns, P. (2009, April). Critical methods and user generated content: The iPhone on YouTube. In Proceedings of the SIGCHI Conference on Human Factors in Computing Systems, 25(2),1467-1476.

Brouwer, B. (2015). YouTube now gets over 400 hours of content uploaded every minute. Retrieved December 20, 2020, from https://www.tubefilter.com/2015/07/26/youtube-400-hourscontentevery-minute/

Burgess, J. E., and Green, J. B. (2009). The entrepreneurial vlogger: Participatory culture beyond the professional-amateur divide. 89-107. National Library of Sweden/Wallflower Press.

Chapple, C., and Cownie, F. (2017). An investigation into viewers' trust in and response towards disclosed paid-for-endorsements by YouTube lifestyle vloggers. Journal of promotional communications, 5(2), 110-136.

Cheung, M. L., Pires, G. D., Rosenberger III, P. J., Leung, W. K., and Ting, H. (2020). Investigating the role of social media marketing on value cocreation and engagement: An empirical study in China and Hong Kong. Australasian Marketing Journal, AMJ, 29(2), 118-131. https://doi.org/10.1016/j.ausmj.2020.03.006.

Choi, G. Y., and Behm-Morawitz, E. (2017). Giving a new makeover to STEAM: Establishing YouTube beauty gurus as digital literacy educators through messages and effects on viewers. Computers in Human Behavior, 73, 80-91.

Choi, W., and Lee, Y. (2019). Effects of fashion vlogger attributes on product attitude and content sharing. Fashion and Textiles, 6(1), 1-18.

Cunningham, S., and Craig, D. (2017). Being 'really real'on YouTube: authenticity, community and brand culture in social media entertainment. Media International Australia, 164(1), 71-81.

De Jans, S., Cauberghe, V., and Hudders, L. (2018). How an advertising disclosure alerts young adolescents to sponsored vlogs: The moderating role of a peer-based advertising literacy intervention through an informational vlog. Journal of Advertising, 47(4), 309-325.

Dehghani, M., Niaki, M. K., Ramezani, I., and Sali, R. (2016). Evaluating the influence of YouTube advertising for attraction of young customers. Computers in human behavior, 59, 165-172.

Dessart, L. (2017). Social media engagement: a model of antecedents and relational outcomes. Journal of Marketing Management, 33(5-6), 375399. 
DeVellis, F.R. (2003). Scale development: Theory and applications. Thousand Oaks: Sage Publication.

Digital 2020 Global Digital Yearbook (2020), Retrieved December 21, 2020, from https://wearesocial.com/digital-2020.

Djafarova, E., and Rushworth, C. (2017). Exploring the credibility of online celebrities Instagram profiles in influencing the purchase decisions of young female users. Computers in Human Behavior, 68, 1-7.

Doyle, J. D., Heslop, L. A., Ramirez, A., and Cray, D. (2012). Trust intentions in readers of blogs. Management Research Review, 35(9), 837-856.

Ducoffe, R. H. (1995). How consumers assess the value of advertising. Journal of Current Issues \& Research in Advertising, 17(1), 1-18.

Ducoffe, R. H. (1996). Advertising value and advertising on the web. Journal of advertising research, 36(5), 21-35.

Fornell, Claes and Larcker F. David (1981). Evaluating structural equation models with unobservable variables and measurement error. Journal of Marketing Research, 18, 39-50.

Glasscock, J. S. P. (2020). Authoritative Knowledge. Erkenntnis, 1-28.

Godey, B., Manthiou, A., Pederzoli, D., Rokka, J., Aiello, G., Donvito, R., and Singh, R. (2016). Social media marketing efforts of luxury brands: Influence on brand equity and consumer behavior. Journal of business research, 69(12), 5833-5841.

Gürkaynak, G., and Kama, Ç. O. (2018). Navigating the uncharted risks of covert advertising in influencer marketing. Business Law Review, 39(1), 17-19.

Haghirian, P., Madlberger, M., and Tanuskova, A. (2005). Increasing advertising value of mobile marketing-an empirical study of antecedents. In System Sciences, 2005. HICSS'05. Proceedings of the 38th Annual Hawaii International Conference On, 32-32. IEEE.

Hair, J. F., Black, W. C., Babin, B. J., Anderson, R. E., and Tatham, R. L. (1998). Multivariate data analysis. Uppersaddle River.

Haridakis, P., and Hanson, G. (2009). Social interaction and co-viewing with YouTube: Blending mass communication reception and social connection. Journal of Broadcasting \& Electronic Media, 53(2), 317-335.

Harnish, R. J., and Bridges, K. R. (2016). Mall haul videos: Selfpresentational motives and the role of self-monitoring. Psychology $\mathcal{E}$ Marketing, 33(2), 113-124. 
Hill, S. R., Troshani, I., and Chandrasekar, D. (2017). Signalling effects of vlogger popularity on online consumers. Journal of Computer Information Systems, 76-84.

Hsu, C. L., Lin, J. C. C., and Chiang, H. S. (2013). The effects of blogger recommendations on customers' online shopping intentions. Internet Research, 23(1), 69-88.

Hsu, C. P., Huang, H. C., Ko, C. H., and Wang, S. J. (2014). Basing bloggers' power on readers' satisfaction and loyalty. Online information review, 38(1), 78-94.

Hudders, L., De Jans, S., and De Veirman, M. (2020). The commercialization of social media stars: a literature review and conceptual framework on the strategic use of social media influencers. International Journal of Advertising, 40(3), 327-375.

Ives, B., Olson, M. H., and Baroudi, J. J. (1983). The measurement of user information satisfaction. Communications of the ACM, 26(10), 785-793.

Johnson, T. J., and Kaye, B. K. (2004). Wag the blog: How reliance on traditional media and the Internet influence credibility perceptions of weblogs among blog users. Journalism \& Mass Communication Quarterly, 81, 622-642.

Khan, M. L. (2017). Social media engagement: What motivates user participation and consumption on YouTube? Computers in human behavior, 66, 236-247.

Klein, R. B., (1998). Principles and practice of structural equation modeling. New York: Guilford.

Ko, H., Cho, C. H., and Roberts, M. S. (2005). Internet uses and gratifications: A structural equation model of interactive advertising, Journal of advertising, 34(2), 57-70.

Koh, J., Kim, Y. G., and Kim, Y. G. (2003). Sense of virtual community: A conceptual framework and empirical validation. International Journal of Electronic Commerce, 8(2), 75-94.

Kozinets, R. V., De Valck, K., Wojnicki, A. C., and Wilner, S. J. (2010). Networked narratives: Understanding word-of-mouth marketing in online communities. Journal of Marketing, 74(2), 71-89.

Kruitbosch, G., and Nack, F. (2008, October). Broadcast yourself on YouTube: Really?. In Proceedings of the 3rd ACM international workshop on Human-centered computing, 7-10. 
Ladhari, R., Massa, E., and Skandrani, H. (2020). YouTube vloggers' popularity and influence: The roles of homophily, emotional attachment, and expertise. Journal of Retailing and Consumer Services, 54, 102027.

Lattin, J., Carroll, D. J., and Green, P. E. (2003). Analyzing Multivariate Data. Duxbury Applied Series. Pasific Grove, CA: Thomson Learning Inc.

Lee, E. J. (2020). Authenticity model of (mass-oriented) computer-mediated communication: Conceptual explorations and testable propositions. Journal of Computer-Mediated Communication, 25(1), 6073.

Lee, J. E., and Watkins, B. (2016). YouTube vloggers' influence on consumer luxury brand perceptions and intentions. Journal of Business Research, 69(12), 5753-5760.

Liu, M. T., Liu, Y., and Zhang, L. L. (2019). Vlog and brand evaluations: The influence of parasocial interaction. Asia Pacific Journal of Marketing and Logistics, 31(2), 419-436.

Lynch, J. (2018). These are the 15 most popular YouTube stars in the world - and some are making millions. Business Insider. Retrieved December 25, 2020, from https://www.businessinsider.de/mostpopular-youtubers-with-most-subscribers-2018-2? $r=\mathrm{US} \& I R=\mathrm{T}$

McQuail, D. (1983). Mass communication Theory: An introduction. Sage: London.

Munnukka, J., Maity, D., Reinikainen, H., and Luoma-aho, V. (2019). Thanks for watching. The effectiveness of YouTube vlogendorsements. Computers in human behavior, 93, 226-234.

Murillo, E., Merino, M., and Núñez, A. (2016). The advertising value of Twitter Ads: A study among Mexican Millennials. Revista brasileira de gestão de negócios, 18(6), 436-456.

Nyagadza, B. (2020). Search engine marketing and social media marketing predictive trends. Journal of Digital Media \& Policy, 11(3), 1-19.

Parboteeah, D. V. (2005). A model of online impulse buying: An empirical study. unpublished doctoral dissertation, Washington State University, Seattle, WA.

Park, D.H., Lee, J. and Han, I. (2007). The effects of on-line consumer reviews on consumer purchasing intention: The moderating role of involvement. International Journal of Electronic Commerce, 11(4), 125-48. 
Peter, J. P. (1981). Construct validity: A review of basic issues and marketing practices. Journal of marketing research, 18(2), 133-145.

Podsakoff, P. M., MacKenzie, S. B., Lee, J. Y., and Podsakoff, N. P. (2003). Common method biases in behavioral research: A critical review of the literature and recommended remedies. Journal of applied psychology, 88(5), 879.

Rahmi, Y., Sekarasih, L., and Sjabadhyni, B. (2016). The influence of beauty vlog on perceived source credibility and purchase intention. Makara Hubs-Asia, 20(2), 13-23.

Ramadanty, S., Muqarrabin, A. M., Nita, W. A., and Syafganti, I. (2020). Examining the effect of persuasive message of beauty vloggers on information acceptance of eWOM and purchase intention: The study of consumers of beauty products in jabodetabek, Indonesia. Pertanika Journal of Social Sciences \& Humanities, 28(2), 763-775.

Sakib, M. N., Zolfagharian, M., and Yazdanparast, A. (2020). Does parasocial interaction with weight loss vloggers affect compliance? The role of vlogger characteristics, consumer readiness, and health consciousness. Journal of Retailing and Consumer Services, 52, https://doi. org/10.1016/j.jretconser.2019.01.002.

Sekaran, U., and Bougie, R. (2016). Research methods for business: A skill building approach. John Wiley \& Sons.

Singh, S., and Sonnenburg, S. (2012). Brand performances in social media. Journal of interactive marketing, 26(4), 189-197.

Smith, A. N., Fischer, E., and Yongjian, C. (2012). How does brand-related user-generated content differ across YouTube, Facebook, and Twitter?, Journal of interactive marketing, 26(2), 102-113.

Stein, J. P., Koban, K., Joos, S., and Ohler, P. (2020). Worth the effort? Comparing different youtube vlog production styles in terms of viewers' identification, parasocial response, immersion, and enjoyment. Psychology of Aesthetics, Creativity, and the Arts, Advance online publication. https://doi.org/10.1037/aca0000374.

Swaminathan, V., Sorescu, A., Steenkamp, J. B. E., O'Guinn, T. C. G., and Schmitt, B. (2020). Branding in a hyperconnected world: Refocusing theories and rethinking boundaries. Journal of Marketing, 84(2), 24-46.

To, P. L., Liao, C., and Lin, T. H. (2007). Shopping motivations on Internet: A study based on utilitarian and hedonic value. Technovation, 27(12), 774-787. 
Veloutsou, C., and Delgado-Ballester, E. (2019). New challenges in brand management. Spanish Journal of Marketing-ESIC, 22(3), 255-272

Wang, C. (2015). Do people purchase what they viewed from Youtube?: The influence of attitude and perceived credibility of user-generated content on purchase intention. MSc Thesis, Florida State University.

Wang, X., and Chang, B. (2020). The impact of the audience's continuance intention towards the vlog: focusing on intimacy, media synchronicity and authenticity. International Journal of Contents, 16(2), 65-77.

Webster, J. G. (2010). User information regimes: How social media shape patterns of consumption. Nw. UL Rev., 104, 593.

Weismueller, J., Harrigan, P., Wang, S., and Soutar, G. N. (2020). Influencer endorsements: How advertising disclosure and source credibility affect consumer purchase intention on social media. Australasian Marketing Journal (AMJ), 28(4), 160-170.

Westbrook, R. A. (1987). Product/consumption-based affective responses and postpurchase processes. Journal of marketing research.24(3), 258270.

Zeithaml, V. A. (1988). Consumer perceptions of price, quality, and value: A means-end model and synthesis of evidence. The Journal of marketing, 52(3), 2-22.

Zhang, H. (2018). Evoking presence in vlogging: A case study of UK beauty blogger Zoe Sugg. First Monday, 23(1), https://doi.org/10.5210/fm.v23i1.8107.

\section{Kaynakça Bilgisi / Citation Information}

Tolunay, A. and Ekizler, H. (2021). Analyzing online shopping behavior from the perspective of Youtube: Do vlog content and vlogger characteristics matter. OPUS-International Journal of Society Research, 18(41), 3041-3065. DOI: 10.26466/opus.874722. 